\title{
Tissue-specific effects of acetylcholine in the canine heart
}

Callø, Kirstine; Goodrow, Robert; Olesen, Søren-Peter; Antzelevitch, Charles; Cordeiro, Jonathan M.

Published in:

A J P: Heart and Circulatory Physiology (Online)

DOI:

10.1152/ajpheart.00029.2013

Publication date:

2013

Document version

Early version, also known as pre-print

Citation for published version (APA):

Callø, K., Goodrow, R., Olesen, S-P., Antzelevitch, C., \& Cordeiro, J. M. (2013). Tissue-specific effects of acetylcholine in the canine heart. A J P: Heart and Circulatory Physiology (Online), 305, H66-H75.

https://doi.org/10.1152/ajpheart.00029.2013 


\section{Tissue-specific effects of acetylcholine in the canine heart}

Kirstine Calloe, Robert Goodrow, Søren-Peter Olesen, Charles Antzelevitch and

\section{Jonathan M. Cordeiro}

Am J Physiol Heart Circ Physiol 305:H66-H75, 2013. First published 3 May 2013;

doi: 10.1152/ajpheart.00029.2013

You might find this additional info useful...

This article cites 35 articles, 20 of which you can access for free at:

http://ajpheart.physiology.org/content/305/1/H66.full\#ref-list-1

Updated information and services including high resolution figures, can be found at: http://ajpheart.physiology.org/content/305/1/H66.full

Additional material and information about American Journal of Physiology - Heart and Circulatory Physiology can be found at:

http://www.the-aps.org/publications/ajpheart

This information is current as of July 4, 2013.

American Journal of Physiology - Heart and Circulatory Physiology publishes original investigations on the physiology of the heart, blood vessels, and lymphatics, including experimental and theoretical studies of cardiovascular function at all levels of organization ranging from the intact animal to the cellular, subcellular, and molecular levels. It is published 24 times a year (twice monthly) by the American Physiological Society, 9650 Rockville Pike, Bethesda MD 20814-3991. Copyright (C) 2013 the American Physiological Society. ESSN: 1522-1539. Visit our website at http://www.the-aps.org/. 


\title{
Tissue-specific effects of acetylcholine in the canine heart
}

\author{
Kirstine Calloe, ${ }^{1,2}$ Robert Goodrow, ${ }^{3}$ Søren-Peter Olesen, ${ }^{2}$ Charles Antzelevitch, ${ }^{3}$ \\ and Jonathan M. Cordeiro ${ }^{3}$ \\ ${ }^{1}$ Department of Veterinary Clinical and Animal Science, University of Copenhagen, Frederiksberg, Denmark; ${ }^{2}$ Danish \\ National Research Foundation Centre for Cardiac Arrhythmia and Department of Biomedical Sciences, Faculty of Health \\ and Medical Sciences, University of Copenhagen, Copenhagen, Denmark; and ${ }^{3}$ Department of Experimental Cardiology, \\ Masonic Medical Research Laboratory, Utica, New York
}

Submitted 10 January 2013; accepted in final form 26 April 2013

Calloe K, Goodrow R, Olesen S, Antzelevitch C, Cordeiro JM. Tissue-specific effects of acetylcholine in the canine heart. Am J Physiol Heart Circ Physiol 305: H66-H75, 2013. First published May 3, 2013; doi:10.1152/ajpheart.00029.2013.-Acetylcholine (ACh) release from the vagus nerve slows heart rate and atrioventricular conduction. ACh stimulates a variety of receptors and channels, including an inward rectifying current [ACh-dependent $\mathrm{K}^{+}$current $\left.\left(I_{\mathrm{K}, \mathrm{ACh}}\right)\right]$. The effect of ACh in the ventricle is still debated. We compared the effect of $\mathrm{ACh}$ on action potentials in canine atria, Purkinje, and ventricular tissue as well as on ionic currents in isolated cells. Action potentials were recorded from ventricular slices, Purkinje fibers, and arterially perfused atrial preparations. Whole cell currents were recorded under voltageclamp conditions, and unloaded cell shortening was determined on isolated cells. The effect of ACh $(1-10 \mu \mathrm{M})$ as well as ACh plus tertiapin, an $I_{\mathrm{K}, \mathrm{ACh}}$-specific toxin, was tested. In atrial tissue, ACh hyperpolarized the membrane potential and shortened the action potential duration (APD). In Purkinje and ventricular tissues, no significant effect of ACh was observed. Addition of ACh to atrial cells activated a large inward rectifying current (from $-3.5 \pm 0.7$ to $-23.7 \pm 4.7 \mathrm{pA} / \mathrm{pF}$ ) that was abolished by tertiapin. This current was not observed in other cell types. A small inhibition of $\mathrm{Ca}^{2+}$ current $\left(I_{\mathrm{Ca}}\right)$ was observed in the atria, endocardium, and epicardium after $\mathrm{ACh}$. $I_{\mathrm{Ca}}$ inhibition increased at faster pacing rates. At a basic cycle length of $400 \mathrm{~ms}$, ACh $(1 \mu \mathrm{M})$ reduced $I_{\mathrm{Ca}}$ to $68 \%$ of control. In conclusion, $I_{\mathrm{K}, \mathrm{ACh}}$ is highly expressed in atria and is negligible/absent in Purkinje, endocardial, and epicardial cells. In all cardiac tissues, ACh caused rate-dependent inhibition of $I_{\mathrm{Ca}}$

Purkinje fiber; atria; ventricle; acetylcholine; ionic currents

ACETYLCHOLINE (ACh) is released from parasympathetic nerves that innervate the sinoatrial and atrioventricular nodes as well as both atria. Cholinergic innervation of the ventricles is believed to be sparse (21). However, this view has lately been challenged, and both porcine atria and ventricles have been shown to be significantly innervated with parasympathetic fibers (32). In the nodes and atria, ACh stimulates a variety of cardiac receptors and channels, but foremost an inward rectifying $\mathrm{K}^{+}$current $\left[\mathrm{ACh}\right.$-dependent $\mathrm{K}^{+}$current $\left.\left(I_{\mathrm{K}, \mathrm{ACh}}\right)\right]$ mediated by heterotetrameric channels formed by Kir3.1 and Kir3.4 $\mathrm{K}^{+}$channel subunits (19). The effects of ACh are not due to direct binding of ACh to Kir3 channels but rather mediated via activation of muscarinic ACh G protein-coupled receptor type 2 (M2). M2 receptors are generally coupled to pertussis toxinsensitive $G$ protein $\left(\mathrm{G}_{0} / \mathrm{G}_{\mathrm{i}}\right)$, and stimulation of $\mathrm{M} 2$ receptors by ACh causes dissociation of the coupled $G$ protein. $G_{\beta \gamma}$ subunits activate the $I_{\mathrm{K}, \mathrm{ACh}}$ channel by direct binding (22),

\footnotetext{
Address for reprint requests and other correspondence: K. Calloe, Dept. of Veterinary Clinical and Animal Science, Univ. of Copenhagen, Rm. 151, Ridebanevej 16,1870 Frederiksberg, Denmark (e-mail: kirstine@callo.dk).
}

whereas $G_{\alpha 0 / I}$ inhibits adenylate cyclase, resulting in a decrease of cAMP. The decrease in cAMP may affect other currents, such as L-type $\mathrm{Ca}^{2+}$ current $\left(I_{\mathrm{Ca}}\right)$ (for a review, see Ref. 2).

Parasympathetic stimulation and activation of $I_{\mathrm{K}, \mathrm{ACh}}$ result in a hyperpolarization of the membrane potential and a slowing of automaticity in sinoatrial node cells (14). In atrial cells, a reduction of the contractile force and a shortening of the action potential (AP) duration (APD) have also been observed (2).

Vagal tone plays a crucial role in atrial fibrillation (AF), and increased activity of $I_{\mathrm{K}, \mathrm{ACh}}$ has been linked to AF in several animal models $(5,18,29)$. Constitutively active $I_{\mathrm{K}, \mathrm{ACh}}$ has been demonstrated in patients with persistent $\mathrm{AF}$, where it may contribute to sustaining the arrhythmia (8). An increase in constitutively active $I_{\mathrm{K}, \mathrm{ACh}}$ has also been demonstrated in the canine atrial tachycardia-remodeled left atrium, and recent studies $(16,24,27)$ have suggested that inhibition of $I_{\mathrm{K} . \mathrm{ACh}}$ may offer an atrium-specific target for the treatment of AF.

While the effect of ACh on atria and nodal tissue is well established, the effect of ACh on Purkinje fibers and ventricular tissues is more controversial. In nondiseased human hearts, low expression of Kir3.1 and 3.4 mRNA has been found in Purkinje fibers. In ventricular tissue, the expression of Kir3.4 is low and Kir3.1 is very small or absent (11), suggesting that these channel subunits are not present. However, a recent study (34) has shown that loss of function mutations in Kir3.4 channels are linked to long QT syndrome (LQTS) in humans.

In canine hearts, some studies have found a differential effect of ACh on ventricular cells since application of ACh had minor effects on the endocardium (Endo) but either abbreviated APD in the epicardium (Epi) (35) or accentuated phase 1 repolarization in Epi, resulting in either a prolongation of APD or a marked abbreviation of APD due to loss of the Epi AP dome (20). Both groups attributed the effect of ACh on ventricular tissue at least partly to inhibition of L-type $I_{\mathrm{Ca}}$, as the effect was more pronounced at fast pacing rates. In line with these observations, the selective $I_{\mathrm{K}, \mathrm{ACh}}$ blocker tertiapin had no effect on APD in canine ventricles at $500-\mathrm{ms}$ basic cycle length (BCL) $(5,15)$.

Many of these observed differences may be due to different recording procedures and species dependence; however, a direct comparison of the effects of ACh on healthy canine atrial, Purkinje, and ventricular cells under similar experimental condition has not been performed. Thus, in the present study, we compared the effect of ACh on APs in canine atria, Purkinje, and ventricular tissue as well as on ionic currents in isolated cells and multicellular preparations. An additional objective of this study was to determine how regional varia- 
tions in the effect of $\mathrm{ACh}$ in the heart could elicit the long QT phenotype caused by mutations in $\operatorname{Kir} 3.4$ ( $\left.I_{\mathrm{K}, \mathrm{ACh}}\right)(34)$.

\section{METHODS}

Experimental animals. This investigation conformed with the National Institutes of Health Guide for Care and Use of Laboratory Animals (NIH Pub. No 85-23, Revised 1996) and was approved by the Animal Care and Use Committee of Masonic Medical Research Laboratory. Adult mongrel dogs of either sex were used in all experiments. Animals were anticoagulated with heparin $(200 \mathrm{IU} / \mathrm{kg})$ and anesthetized with pentobarbital $(35 \mathrm{mg} / \mathrm{kg}$ iv). Their hearts were rapidly removed and placed in cold $\left(4^{\circ} \mathrm{C}\right)$ cardioplegic solution containing (in mM) $129 \mathrm{NaCl}, 12 \mathrm{KCl}, 0.9 \mathrm{NaH}_{2} \mathrm{PO}_{4}, 20 \mathrm{NaHCO}_{3}$, $1.8 \mathrm{CaCl}_{2}, 0.5 \mathrm{MgSO}_{4}$, and 5.5 glucose (pH 7.4).

Atrial preparation. Canine right atrial preparations were isolated and perfused through the ostium of the right coronary artery. During the cannulation procedure, preparations were perfused with cardioplegic solution $\left(4^{\circ} \mathrm{C}\right.$ Tyrode solution containing $\left.12 \mathrm{mM} \mathrm{KCl}\right)$, and arterial branches were ligated using silk ligatures. Preparations were placed in a tissue bath and perfused with Tyrode solution consisting of (in $\mathrm{mM}$ ) $129 \mathrm{NaCl}, 4 \mathrm{KCl}, 0.9 \mathrm{NaH}_{2} \mathrm{PO}_{4}, 20 \mathrm{NaHCO}_{3}, 1.8 \mathrm{CaCl}_{2}, 0.5$ $\mathrm{MgSO}_{4}$, and 5.5 glucose ( $\mathrm{pH} 7.4$ ) and bubbled with $95 \% \mathrm{O}_{2}-5 \% \mathrm{CO}_{2}$ $\left(37 \pm 0.5^{\circ} \mathrm{C}\right)$. The perfusate was delivered at a constant flow. Pacing stimuli were delivered to the Endo surface at two times the diastolic excitability at a BCL of $1 \mathrm{~s}$. Intracellular recordings were obtained using floating glass microelectrodes from the pectinate muscle 1-1.5 $\mathrm{h}$ after muscles were mounted. AP signals were amplified, digitized, and analyzed using Spike 2 softward for Windows [Cambridge Electronic Design (CED), Cambridge, UK].

Slice preparation and Purkinje fibers. Purkinje fibers were dissected out from both ventricles of canine hearts kept in cold cardiople-

A

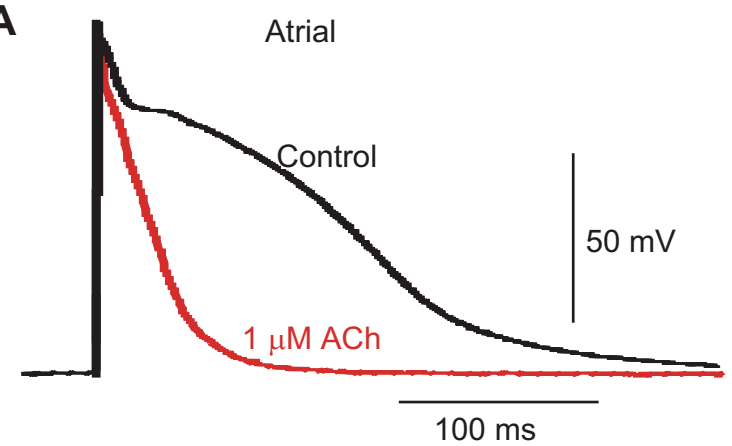

C

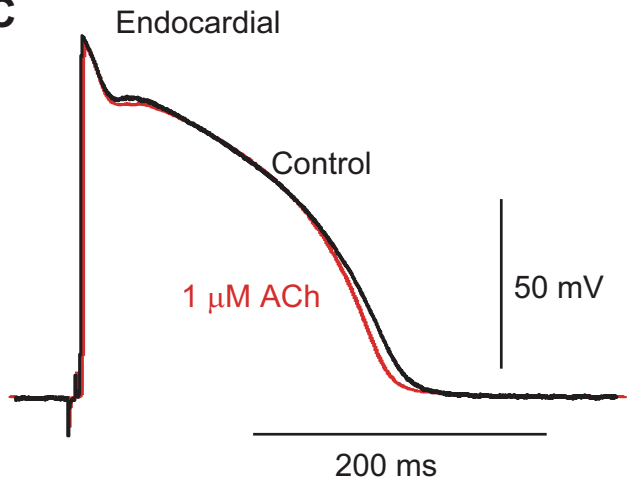

gic Tyrode solution. Thin sheets of sub-Epi or sub-Endo muscle were shaved from the left ventricle using a dermatome (Davol, Cranston, RI). Preparations were pinned in a tissue bath superfused with Tyrode solution bubbled with $95 \% \quad \mathrm{O}_{2}-5 \% \quad \mathrm{CO}_{2}$ and maintained at $37^{\circ} \mathrm{C}$. Fibers or slices were stimulated through silver bipolar electrodes, and impulses were delivered at 1,000- or 2,000-ms BCL. Pulses were two times the diastolic threshold intensity for 2-ms duration. Preparations were equilibrated with normal Tyrode solution for 3-5 h before recordings. APs were recorded using glass microelectrodes filled with 2.7 $\mathrm{M} \mathrm{KCl}$ (15- to 30-M $\Omega$ resistance) connected to dual microprobe systems (WP Instruments, New Haven, CT), amplified with a programmable amplifier, and digitized (model 1401 A/D System, CED). Spike 2 software (CED) was used for acquisition and analysis.

Isolation of adult canine cardiomyocytes. Left ventricular or left atrial preparations were dissected as previously described $(3,6)$. A wedge consisting of the left ventricular free wall supplied by a descending branch of the circumflex artery was excised, cannulated, and initially perfused with nominally $\mathrm{Ca}^{2+}$-free Tyrode solution containing $0.1 \%$ BSA and bubbled with $95 \% \mathrm{O}_{2}-5 \% \mathrm{CO}_{2}$ for a period of $\sim 5 \mathrm{~min}$. The preparation was then subjected to enzyme digestion with nominally $\mathrm{Ca}^{2+}$-free solution supplemented with $0.5 \mathrm{mg} / \mathrm{ml}$ collagenase (type II, Worthington), $0.1 \mathrm{mg} / \mathrm{ml}$ protease (type XIV, Sigma), and $1 \mathrm{mg} / \mathrm{ml} \mathrm{BSA}$ for $8-12 \mathrm{~min}$. For the isolation of ventricular cells, thin slices of tissue from the Epi and Endo were shaved from the wedge using a dermatome. For atrial cells, the pectinate muscle was isolated. The tissue was then placed in separate beakers, minced, incubated in fresh buffer containing $0.5 \mathrm{mg} / \mathrm{ml}$ collagenase and $1 \mathrm{mg} / \mathrm{ml} \mathrm{BSA}$, and agitated. The isolation process was performed at $37^{\circ} \mathrm{C}$. The supernatant was filtered and centrifuged at $200 \mathrm{rpm}$ for $2 \mathrm{~min}$, and the myocyte-containing pellet was stored in $0.5 \mathrm{mM} \mathrm{Ca}^{2+}$ HEPES buffer containing (in $\mathrm{mM}$ ) $126 \mathrm{NaCl}, 5.4 \mathrm{KCl}$,
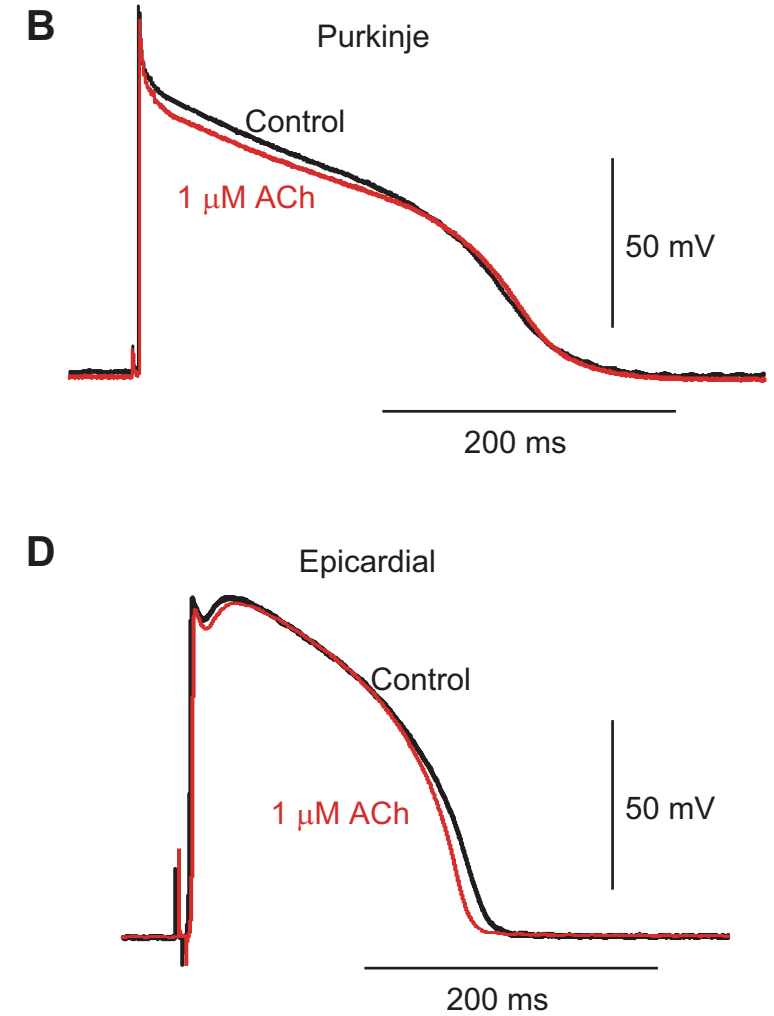

Fig. 1. Action potential (AP) recordings from a canine heart in the absence or presence of ACh. A: preparations of arterially perfused canine atria. $B-D$ : free-running Purkinje strands $(B)$ or thin tissue slices from the endocardium (Endo; $C$ ) or epicardium (Epi; $D$ ) were paced at 1,000- or 2,000-ms basic cycle length (BCL) in the absence or presence of $1-10 \mu \mathrm{M}$ ACh or $10 \mu \mathrm{M} \mathrm{ACh}+100 \mathrm{nM}$ tertiapin (Tert). Representative recordings at 1,000-ms BCL in the absence or presence of $1 \mu \mathrm{M}$ ACh are shown. 
$1.0 \mathrm{MgCl}_{2}, 0.5 \mathrm{CaCl}_{2}, 10$ HEPES, and 11 glucose ( $\mathrm{pH}$ adjusted to 7.4 with $\mathrm{NaOH}$ ) at room temperature.

Isolation of Purkinje cells. Canine Purkinje cells were isolated using previously described techniques (9). Briefly, Purkinje fibers from both ventricles were dissected out and placed in a small dish. Fibers were then subjected to enzyme digestion with nominally $\mathrm{Ca}^{2+}$-free solution supplemented with $1.0 \mathrm{mg} / \mathrm{ml}$ collagenase (type II, Worthington) and $30 \mathrm{mM}$ 2,3-butanedione monoxime (BDM) at $36^{\circ} \mathrm{C}$. Dissociation of cells from the fibers was aided by agitation of the enzyme solution with a small stir bar. Periodically, the enzyme solution containing Purkinje cells in suspension was removed and added to a modified storage solution (described above). Fresh enzyme solution was added to the undigested Purkinje fibers to maintain a volume of $\sim 2 \mathrm{ml}$. Digestion of the Purkinje fibers into individual myocytes typically required $15-35 \mathrm{~min}$. Cells were kept in low-Ca ${ }^{2+}$ storage solution at room temperature until use.

Voltage-clamp recordings. Voltage-clamp recordings were made using a MultiClamp 700A amplifier and MultiClamp Commander (Axon Instruments). Patch pipettes were fabricated from borosilicate glass capillaries (1.5-mm outer diameter, Fisher Scientific, Pittsburgh, PA). Pipettes were pulled using a gravity puller (Narishige, Tokyo, Japan), and the pipette resistance ranged from 1 to $3 \mathrm{M} \Omega$. For recording of inward rectifier currents, cardiomyocytes were superfused with HEPES buffer of the following composition (in $\mathrm{mM}$ ): 126 $\mathrm{NaCl}, 5.4 \mathrm{KCl}, 1.0 \mathrm{MgCl}_{2}, 2.0 \mathrm{CaCl}_{2}, 10$ HEPES, and 11 glucose $(\mathrm{pH}$ adjusted to 7.4 with $\mathrm{NaOH}$ ). The patch pipette solution had the following composition (in $\mathrm{mM}$ ): $90 \mathrm{~K}$-aspartate, $30 \mathrm{KCl}, 5.5$ glucose, $1.0 \mathrm{MgCl}_{2}$, 5 EGTA, $5 \mathrm{MgATP}, 0.1 \mathrm{Na}_{3}$ GTP, 5 HEPES, and $10 \mathrm{NaCl}$
( $\mathrm{pH} 7.2$ with $\mathrm{KOH}$ ). For $I_{\mathrm{Ca}}$ recordings, the patch pipette contained (in $\mathrm{mM}) 120 \mathrm{CsCl}, 1.0 \mathrm{MgCl}_{2}, 10$ EGTA, $5 \mathrm{MgATP}, 10 \mathrm{HEPES}$, and 5 $\mathrm{CaCl}_{2}$ (pH 7.2 with $\mathrm{CsOH}$ ). The external solution contained (in $\mathrm{mM}$ ) $140 \mathrm{~N}$-methyl-D-glucamine, 10 glucose, $1.8 \mathrm{CaCl}_{2}, 1.0 \mathrm{MgCl}_{2}$, and 10 HEPES ( $\mathrm{pH} 7.4$ with $\mathrm{HCl}$ ). The extracellular solution was locally applied to cells using a micromanifold apparatus. This method ensures a rapid response and prevents compounds released from unhealthy cells in the perfusion bath (such as adenosine, for example) from interacting with the cell being patched (7). All experiments were performed at $37^{\circ} \mathrm{C}$. After a whole cell patch was established, cell capacitance $\left(C_{\mathrm{m}}\right)$ was measured by applying $-5-\mathrm{mV}$ voltage steps. Electronic compensation of series resistance to $60-70 \%$ was applied to minimize voltage errors. All analog signals were acquired at 10-50 $\mathrm{kHz}$, filtered at $4-6 \mathrm{kHz}$, digitized with a Digidata 1322 converter (Axon Instruments), and stored using pClamp9 software

Statistical analysis. Data are presented as means \pm SE. Statistical comparisons were made using paired or unpaired Student's $t$-tests or one-way ANOVA followed by a Student-Newman-Keuls posttest for multiple comparisons. $P<0.05$ was considered statistically significant.

\section{RESULTS}

The effect of ACh on atrial tissue is well documented, so as an initial basis for comparison, we tested the effect of ACh (1 $\mu \mathrm{M})$ on arterially perfused atrial preparations. Application of ACh resulted in a marked shortening of APD at $90 \%$ repolarization (Fig. 1A).
Fig. 2. Summarized data of AP parameters in the absence or presence of ACh. Preparations of arterially perfused canine atria, free running Purkinje strands, or tissue slices from the Endo or Epi were paced at 1,000- or 2,000-ms BCL in the absence or presence of $1^{\mathrm{TM}} 10 \mu \mathrm{M}$ ACh or $10 \mu \mathrm{M}$ ACh $+100 \mathrm{nM}$ Tert. $A$ and $B$ : bar graphs showing the effect of ACh on AP duration (APD) at $90 \%$ repolarization $\left(\mathrm{APD}_{90} ; A\right)$ and on resting membrane potential $\left(E_{\text {rest }} ; B\right)$ at different pacing rates and $\mathrm{ACh}$ concentrations. The effect of ACh on Purkinje, Endo, or Epi APs was not significant.
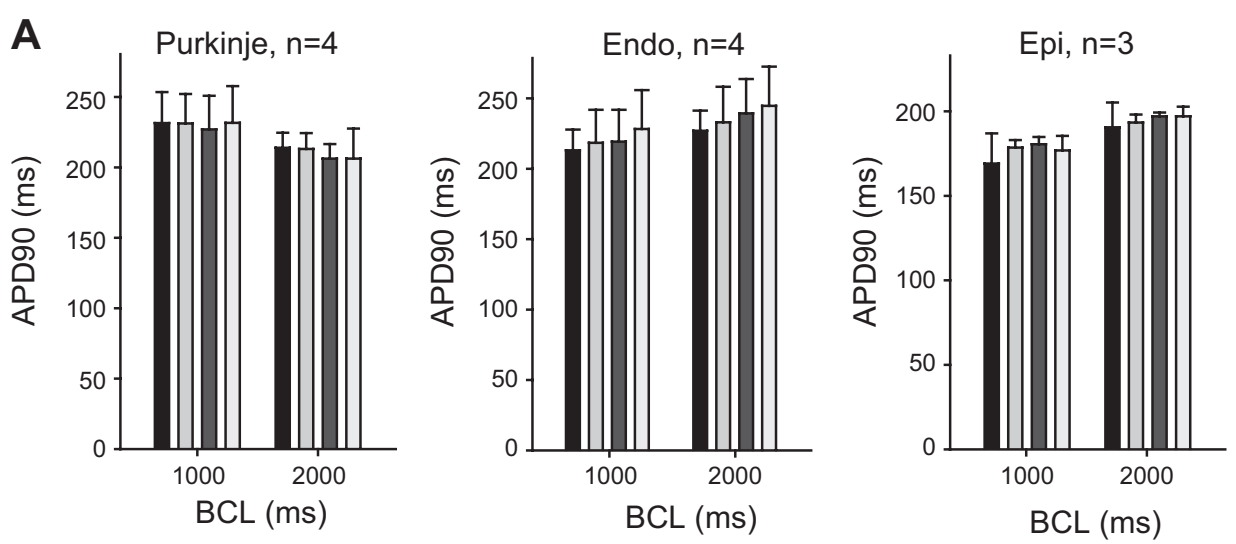

B

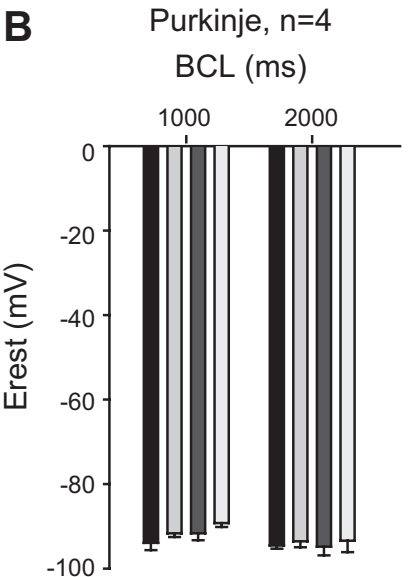


In contrast, the response to $\mathrm{ACh}$ in nonatrial tissues was minimal. We applied ACh to Epi and Endo tissue slice preparations paced at 1,000- and 2,000-ms BCL. ACh $(1 \mu \mathrm{M})$ had no significant effect on AP morphology, APD, or resting membrane potential (Fig. 1, $C$ and $D$ ), and similar results were found for Purkinje fibers (Fig. 1B). Increasing the concentration of ACh to $10 \mu \mathrm{M}$ did not alter electrical properties in Purkinje, Endo, or Epi tissue. Finally, application of the $I_{\mathrm{K}, \mathrm{ACh}^{-}}$ specific toxin tertiapin $(100 \mathrm{nM})$ in the continued presence of $10 \mu \mathrm{M}$ ACh was without effect. Mean data are shown in Fig. 2. For Purkinje, Epi, and Endo preparations, upstroke velocity, AP amplitude, and APD at 50\% repolarization were also evaluated at different pacing rates and ACh concentra- tions, but none of these parameters was significantly affected by ACh (data not shown).

To test the effect of $\mathrm{ACh}$ on ionic currents, cells were isolated from atria, Purkinje fibers, and the Endo and Epi. $C_{\mathrm{m}}$ was determined by a short $5-\mathrm{mV}$ pulse $\left(C_{\mathrm{m}}\right.$ in atria: $91.5 \pm 4.9$ pF, $n=5$; Endo: $172.4 \pm 17.8$ pF, $n=9$; Epi: $191.0 \pm 14.5$ pF, $n=8$; and Purkinje: $217.4 \pm 27.0 \mathrm{pF}, n=8$ ). To limit time-dependent changes, whole cell currents were activated by a step to $-10 \mathrm{mV}$ followed by a $500-\mathrm{ms}$ ramp to $-120 \mathrm{mV}$ from a holding potential of $-80 \mathrm{mV}$, roughly mimicking the shape of an AP. No blockers were added to the recording solution as the activation pulse would activate and eliminate $\mathrm{Na}^{+}$current $\left(I_{\mathrm{Na}}\right)$ and $I_{\mathrm{Ca}}$. The inward current at the end of the
A

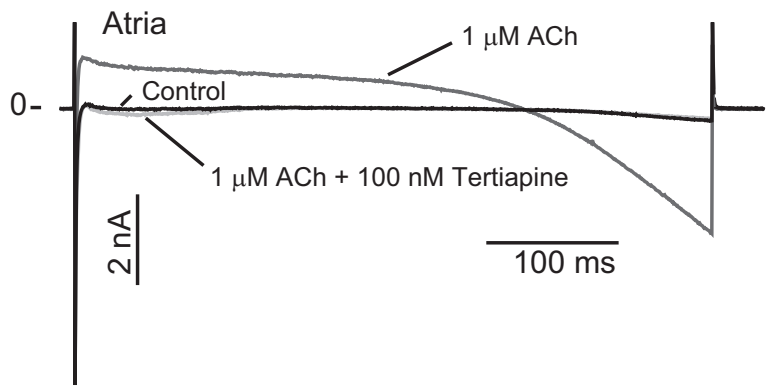

C

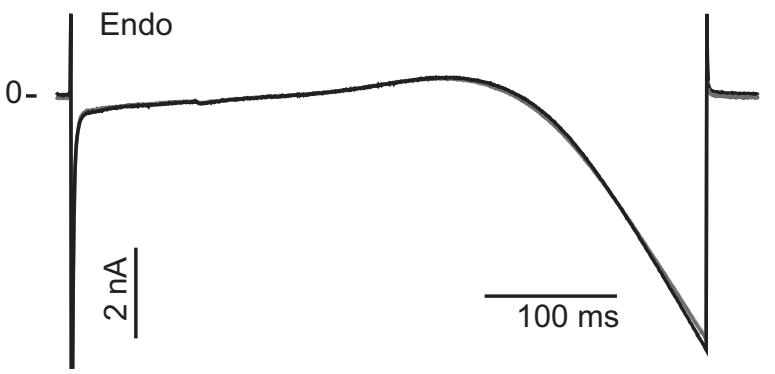

E

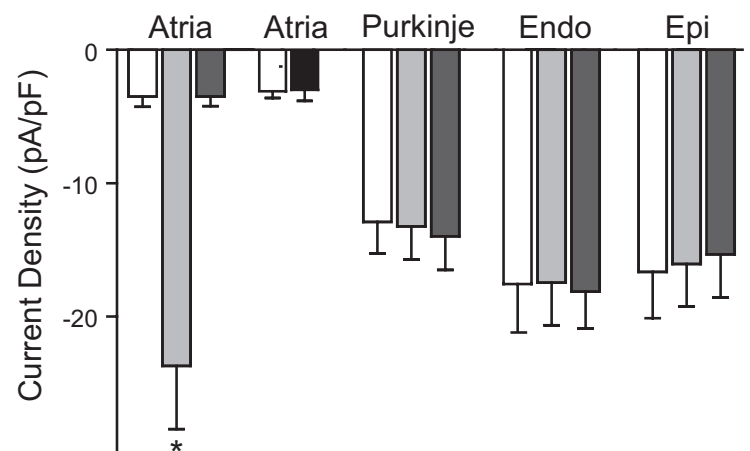

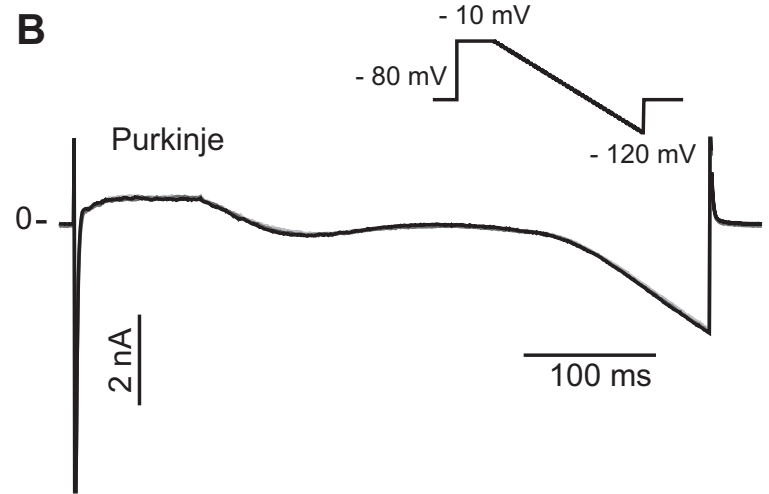

D

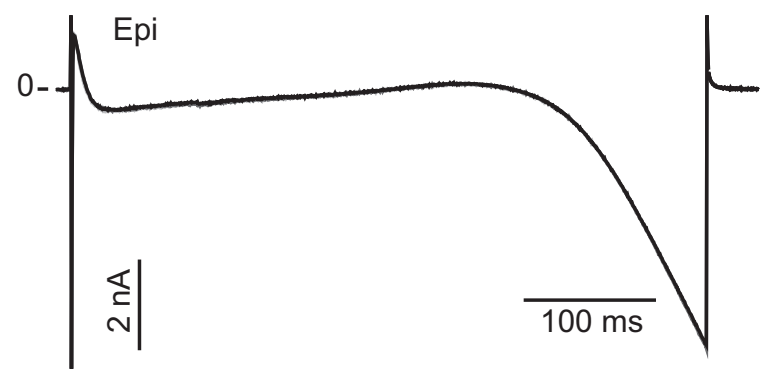

$\mathbf{F}$

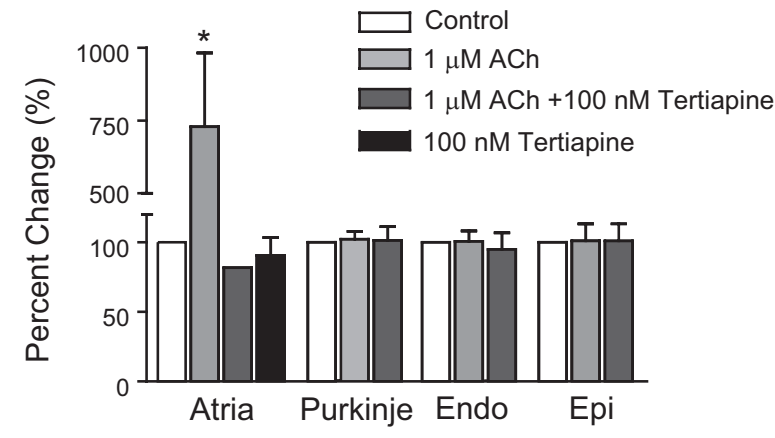

Fig. 3. Whole cell currents from isolated canine atrial $(n=5)$, Purkinje $(n=8)$, Endo $(n=5)$, and Epi $(n=8)$ cells. Total ionic currents were elicited by a ramp protocol. $A-D$ : representative recordings in the absence (black) or presence of $1 \mu \mathrm{M}$ ACh (dark gray) and $1 \mu \mathrm{M}$ ACh $+100 \mathrm{nM}$ Tert (light gray) in atrial $(A)$, Purkinje $(B)$, Endo $(C)$, and Epi $(D)$ cells. For atrial cells, the effect of $100 \mathrm{nM}$ Tert on cells that were not preexposed to ACh was also addressed $(n=5)$. $E$ : bar graph showing the effect of ACh on the density of inward currents measured at the end of the ramp protocol. $F$ : normalized effect of ACh on inward current density. 
ramp protocol, likely due to the inward rectifying $\mathrm{K}^{+}$channel $(23,30)$, was small in the atria, intermediate in Purkinje cells, and large in Endo and Epi cells. ACh $(1 \mu \mathrm{M})$ was rapidly applied, and the effect of ACh was confirmed by applying 100 $\mathrm{nM}$ tertiapin in the continued presence of ACh. Representative recordings are shown in Fig. 3, $A-D$. In atrial cells, ACh activated a large inwardly rectifying current that could be completely abolished by application of the $I_{\mathrm{K}, \mathrm{ACh}}$ blocker tertiapin. Application of $100 \mathrm{nM}$ tertiapin to atrial cells that had not been exposed to ACh had no significant effect on constitutively active current density, and control currents were $-2.56 \pm$ $0.42 \mathrm{pA} / \mathrm{pF}$ and $-2.47 \pm 0.70 \mathrm{pA} / \mathrm{pF}$ in the presence of tertiapin $(n=5$; Fig. 3E). In contrast, no effect of ACh or ACh + tertiapin was found in Purkinje, Endo, or Epi cells. Summarized data for the effect on current density at the end of the ramp protocol are shown in Fig. 3, $E$ and $F$.

We next measured the effect of ACh in the four cell types by application of square-wave voltage-clamp pulses. Currents were elicited by step increments of $10 \mathrm{mV}$ between -120 and $+30 \mathrm{mV}$ from a holding potential of $-80 \mathrm{mV}$ (Fig. 4). Similar to the ramp protocol, large steady-state inward currents could be observed in cells from the Endo and Epi, and an intermediate current was found in Purkinje cells in response to hyperpolarizing voltage, whereas steady-state current was small in atrial cells. Currents were evaluated at the end of the 500-ms step pulse, where $I_{\mathrm{Na}}$ and $I_{\mathrm{Ca}}$ were discharged and inactivated. Application of $1 \mu \mathrm{M}$ ACh had no effect on currents recorded from Endo, Epi, or Purkinje cells, but, as expected, in atrial cells, application of ACh increased currents from $-3.7 \pm 0.7$ to $-30.4 \pm 7.7 \mathrm{pA} / \mathrm{pF}$ at $-120 \mathrm{mV}(n=6, P<0.05)$. The effect of ACh on steady-state currents is shown in Fig. $4 B$.

It has been previously suggested that ACh can affect $I_{\mathrm{Ca}}$ in ventricular tissue $(20,35)$. In the next series of experiments, we investigated the effect of ACh on $I_{\mathrm{Ca}}$ in atrial, Endo, Epi, and Purkinje cells. $I_{\mathrm{Ca}}$ was elicited by application of a 300-ms step depolarization from -80 to $0 \mathrm{mV}$. Extended protocols were avoided to prevent current rundown. Representative currents in the absence or presence of $1 \mu \mathrm{M}$ ACh are shown in Fig. $5 A$, and the effect on $I_{\text {Ca }}$ peak current density is shown in Fig. $5 B$. ACh significantly reduced $I_{\mathrm{Ca}}$ in atrial, Endo, and Epi cells.

The effect of ACh on $I_{\mathrm{Ca}}$ may be dependent on pacing frequency $(20,35)$, and, in the next series of experiments, we investigated the effect of $\mathrm{ACh}$ on isolated Epi myocytes at different stimulation rates (Fig. 6). At fast pacing rates, $I_{\mathrm{Ca}}$ becomes progressively smaller. In the presence of $1 \mu \mathrm{M} \mathrm{ACh}$, the reduction was more pronounced at faster pacing rates, and, at $400-\mathrm{ms} \mathrm{BCL}, I_{\mathrm{Ca}}$ was significantly reduced to $68.7 \pm 8.7 \%$ $(n=7)$ of control by $1 \mu \mathrm{M}$ ACh.

The reduction in $I_{\mathrm{Ca}}$ would suggest that contractility would be reduced. In a final set of experiments, we tested the effect of ACh on unloaded cell shortening of enzymatically dissociated canine atrial, Purkinje, Endo, and Epi cells (Fig. 7). Cells were stimulated at 1,000- or 2,000-ms BCL. In atrial cells, $1 \mu \mathrm{M}$ ACh completely abolished contraction. For Epi cells, there was a small but significant inhibition of contraction; at 1,000-ms $\mathrm{BCL}$, fractional shortening was reduced by $16 \%$ by $1 \mu \mathrm{M} \mathrm{ACh}$. This inhibition was reversible upon washout. In Endo cells, there was a tendency toward a reduction in fractional shortening, but it did not reach significance. Interestingly, in some Purkinje cells, $1 \mu \mathrm{M}$ ACh increased contraction, whereas in other cells, it decreased cell shortening. These disparate results may be due to the long morphology of the Purkinje cell coupled with the asynchronous nature of contractions.

\section{DISCUSSION}

Summary of main findings. In the present study, we sought to determine the mechanism by which loss of function mutations in $\operatorname{Kir} 3.4\left(I_{\mathrm{K}, \mathrm{ACh}}\right)$ identified in a large family could elicit the long QT phenotype. To this end, we compared the effect of $\mathrm{ACh}$ on AP morphology in canine arterially perfused atria and superfused isolated Purkinje fibres as well as Endo and Epi tissue slices. Ionic currents were recorded from isolated myocytes and fractional cell shortening under similar recording
A
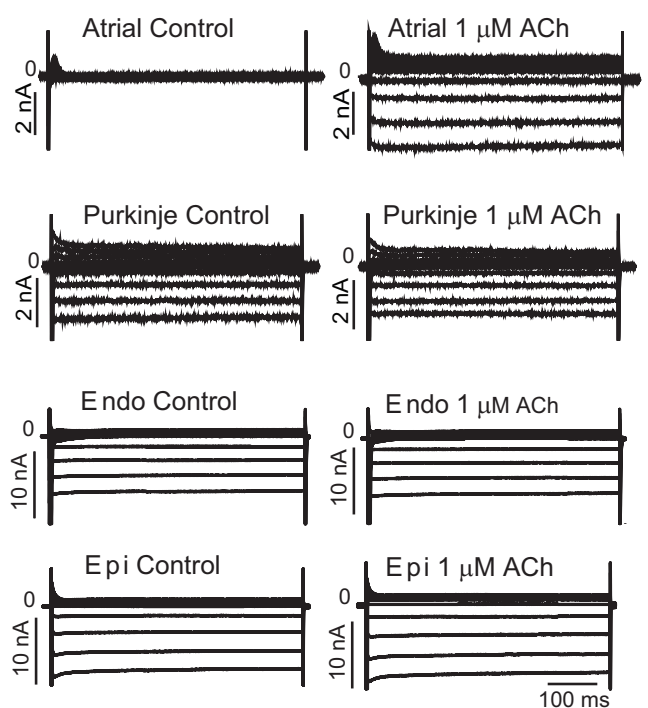
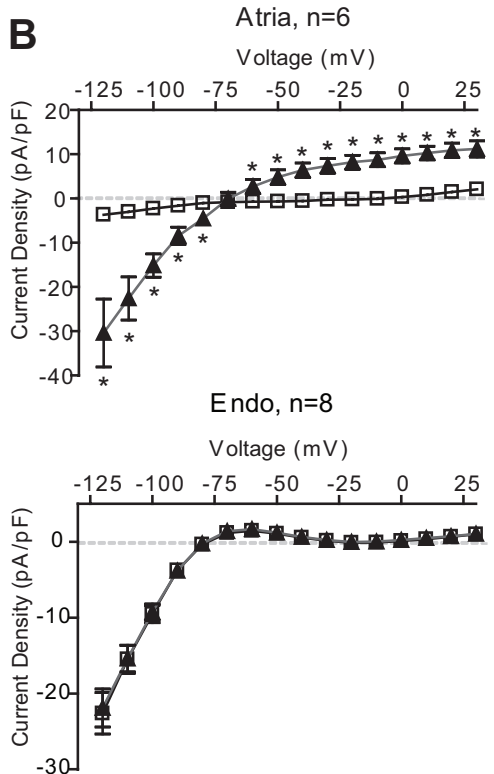
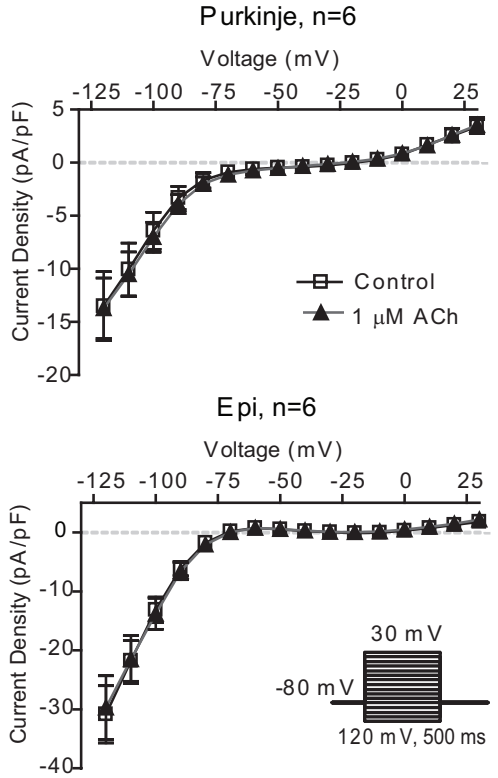

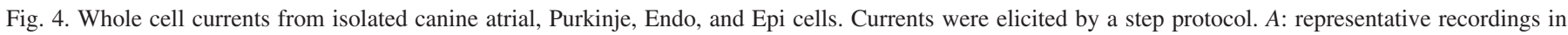
the absence or presence of $1 \mu \mathrm{M}$ ACh. $B$ : steady-state current-voltage relationship in the absence or presence of ACh. ${ }^{*} P<0.05$. 
conditions. In perfused atrial preparations, the results showed that ACh abbreviated APD and hyperpolarized the membrane potential, mainly due to activation of tertiapin-sensitive $I_{\mathrm{K}, \mathrm{ACh}}$. In canine Purkinje, Endo, and Epi myocytes, $I_{\mathrm{K}, \mathrm{ACh}}$ was absent, suggesting that $I_{\mathrm{K}, \mathrm{ACh}}$ does not contribute to the repolarizing reserve in the canine ventricle or Purkinje network. A minor frequency-dependent block of $I_{\mathrm{Ca}}$ was found, which may explain the minor effects of ACh on AP morphology and contraction noted in preparations from Endo, Epi, or Purkinje fibers.

Effect of ACh on atrial cells. The effect of ACh on atrial tissue and myocytes is well documented (2). In agreement with previous studies, ACh increased $I_{\mathrm{K}, \mathrm{ACh}}$ in atrial cells, resulting in a shortening of APD and a hyperpolarization of the resting membrane potential. Application of tertiapin in the continued presence of ACh resulted in currents that could be superimposed with control recordings, suggesting that there is no sustained $I_{\mathrm{K}, \mathrm{ACh}}$ in healthy canine atria and that the effect of $\mathrm{ACh}$ is mainly due to activation of $I_{\mathrm{K}, \mathrm{ACh}}$. Our results are consistent with previous studies $(17,25)$ demonstrating that in the absence of ACh, single-channel openings of $I_{\mathrm{K}, \mathrm{ACh}}$ channels in atrial cells were sporadically observed. Interestingly, sustained or constitutively active $I_{\mathrm{K}, \mathrm{ACh}}$ (in the absence of $\mathrm{ACh}$ ) has been reported in both healthy controls and from atrial tachypaced dogs (5). In contrast, Makary et al. (25) measured constitutively active $I_{\mathrm{K}, \mathrm{ACh}}$ only in diseased atria and determined that elevations in intracellular $\mathrm{Ca}^{2+}$ were central to the appearance of constitutively active current. Since our pipette solution contained $5 \mathrm{mM}$ EGTA, we presumed that this concentration of EGTA could suppress elevations in intracellular $\mathrm{Ca}^{2+}$ and constitutively active $I_{\mathrm{K}, \mathrm{ACh}}$. However, in the original reports of constitutively active $I_{\mathrm{K}, \mathrm{ACh}}$, EGTA-containing pipette solutions were used $(5,8,10)$, and other experimental conditions may contribute to the discrepancies between the results.

Effect of ACh on Purkinje cells. The effect of ACh on Purkinje fibers has yielded conflicting results, suggesting species-specific responses. In rabbit Purkinje fibers, application of
A
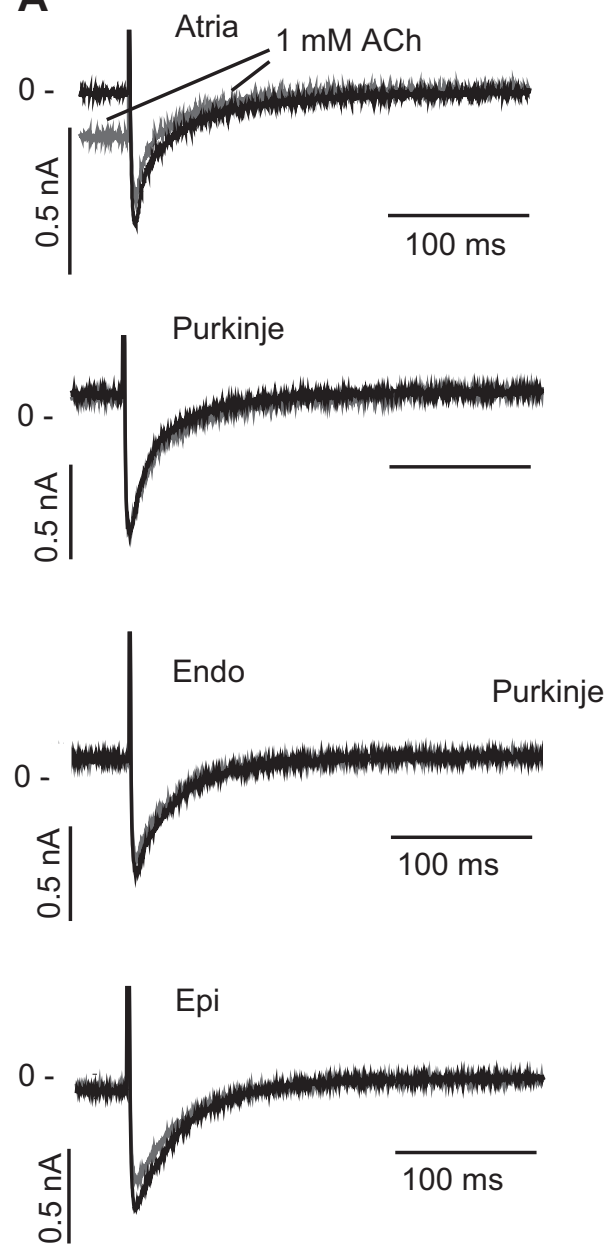

B
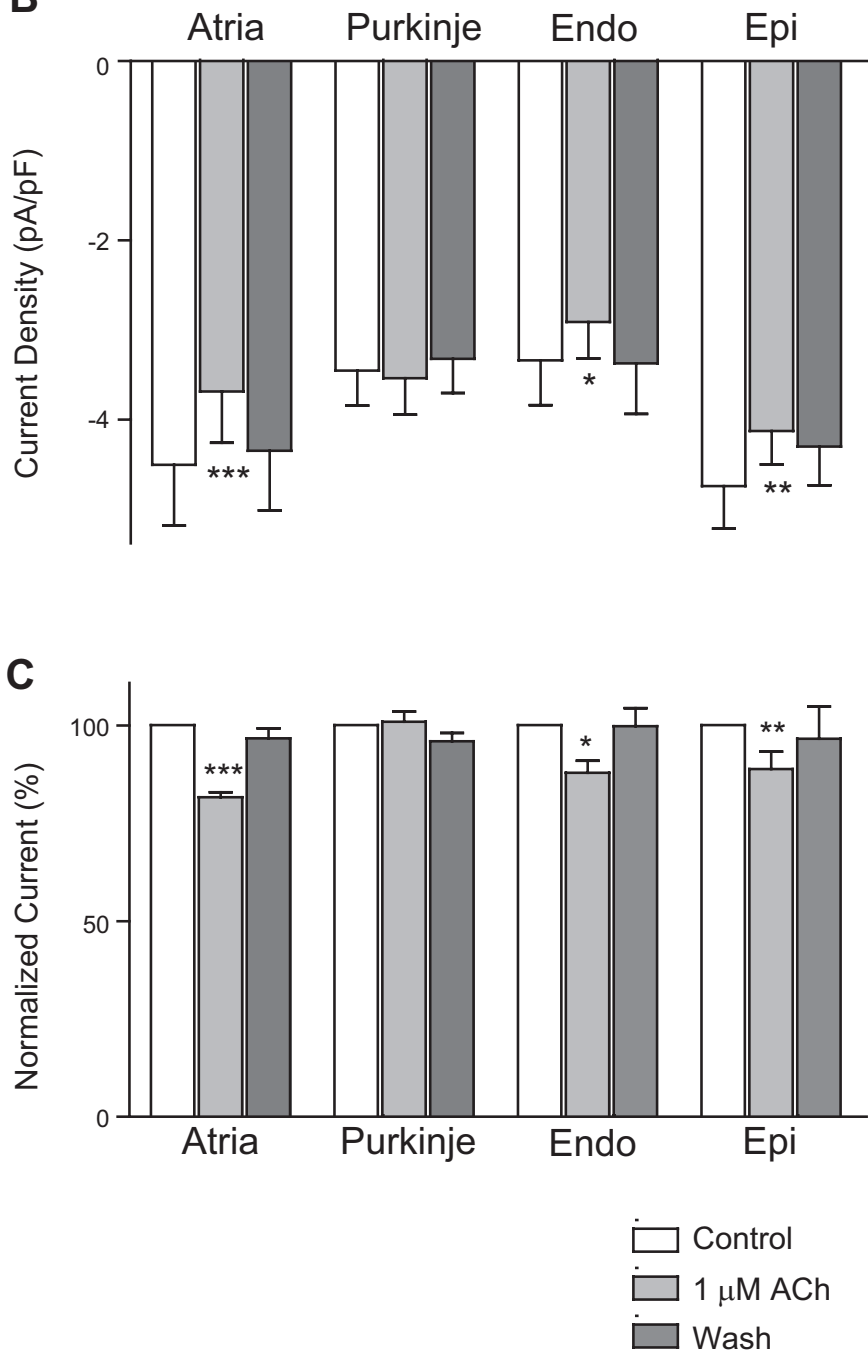

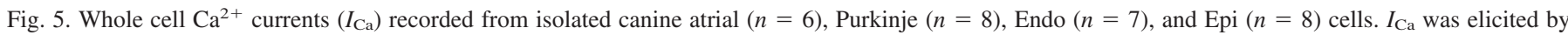

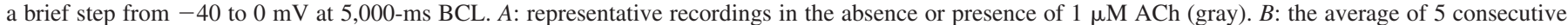

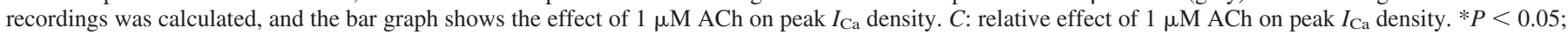
$* * P<0.01 ; * * * P<0.001$ 
ACh resulted in an abbreviation of APD due to activation of $I_{\mathrm{K}, \mathrm{ACh}}(26)$. In contrast, ACh prolonged APD in sheep Purkinje fibers (4), suggesting increased outward current or reduced inward currents. A previous study (1) involving canine His bundle and right bundle branch preparations demonstrated that in the nodal and proximal His bundle, APs exhibited a spontaneous diastolic depolarization. In these cells, ACh reduced the slope of the diastolic depolarization and the automaticity of the tissue. The takeoff potential became more negative, and AP amplitude and upstroke velocity increased. In the more distal right bundle branch, APs did not exhibit a spontaneous depolarization and were not affected by ACh (1). In canine freerunning Purkinje fibers isolated from the ventricular walls, an abbreviation of APD at $90 \%$ repolarization by ACh (12) and hyperpolarization of the resting membrane potential have been reported (13). However, in agreement with Gilmour and Zipes (13), we found no effect of ACh $(10 \mu \mathrm{M})$ on AP morphology, $\mathrm{APD}$, or resting membrane potential in free-running Purkinje strands. In enzymatically dissociated Purkinje cells, the absence of tertiapin-sensitive $I_{\mathrm{K}, \mathrm{ACh}}$ was confirmed, and ACh had no effect on whole cell ionic currents elicited by either a voltage-ramp or voltage-step protocol. These observations could suggest a differential expression of $I_{\mathrm{K}, \mathrm{ACh}}$ in the proximal and distal parts of the His-Purkinje system.

The Purkinje fiber network may play an important role in triggering arrhythmias associated with LQTS (28). Since we observed no effect of ACh in ventricular tissue, we speculated if $I_{\mathrm{K}, \mathrm{ACh}}$ was present in the Purkinje network as it may explain the long QT phenotype of mutation carriers (34). However, we could not identify a mechanism by which the Kir3.4 mutation produces the long QT phenotype (presumably due to species differences between humans and dogs). In humans, Purkinje fibers exhibited low expression of Kir3.1 and Kir3.4 (compared with atria), predicting a lesser effect of ACh on the Purkinje fiber AP (11).

Effect of ACh on ventricular cells. A recent interest in ventricular $I_{\mathrm{K}, \mathrm{ACh}}$ has been sparked by the quest for atriumspecific drugs that are devoid of ventricular proarrhythmic effects. Thus, several studies have investigated the effect of tertiapin and other $I_{\mathrm{K}, \mathrm{ACh}}$ blockers on ventricular tissue. In anesthetized dogs, vagal nerve stimulation and application of tertiapin did not affect ventricular ECG parameters at 200- or 300-ms BCL (15). In canine ventricular wedge preparations, tertiapin had no effect on APD at a BCL of $500 \mathrm{~ms}$, and no tertiapin-sensitive current was found in isolated ventricular cells (5). Similar results were obtained in anesthetized dogs using the $I_{\mathrm{K}, \mathrm{ACh}}$ blocker NIP-151 (16). Similarly, we did not find a tertiapin-sensitive current in isolated ventricular myocytes or in Epi or Endo slices. Interestingly, previous studies have suggested that ACh has an effect on AP morphology and contraction of canine ventricular tissue. A previous report (20) showed that $1 \mu \mathrm{M}$ ACh increased phase 1 repolarization, which resulted in an increase in APD in Epi slices due to accentuation of the AP notch. At faster rates (300- to 500-ms BCL), ACh caused a marked abbreviation of the Epi AP due to loss of the AP dome. Only minor effects were observed slower rates (1,000- or 2,000-ms BCL) (20). In our study, ACh (1-10 $\mu \mathrm{M})$ did not alter APD or resting membrane potential in endocardial tissue slices or cells at slow pacing rates. In canine ventricular myocytes, Yang et al. found that ACh had little effect on the phase 1 repolarization of isolated Epi cells but depressed the plateau phase and shortened APD at 1,000-ms BCL. In both studies, the effect of ACh was most prominent in the Epi, whereas the effect in the Endo was neglible $(20,35)$, and it was concluded that the alterations in AP were due to a decrease in $I_{\mathrm{Ca}}$ rather than activation of $I_{\mathrm{K}, \mathrm{ACh}}$. However, the
Fig. 6. Representative whole cell recordings showing time course of changes in $I_{\mathrm{Ca}}$ from a left ventricular Epi myocyte. The cell was activated 35 times at various stimulation rates, and every pulse is shown. $A: I_{\mathrm{Ca}}$ was activated at 2,000-ms BCL for 35 pulses. In the absence of drug and at slow pacing rates, each $I_{\mathrm{Ca}}$ was superimposable. $B$ : in the presence of $1 \mu \mathrm{M}$ $\mathrm{ACh}$ and at an activation rate of 400-ms BCL, the size of $I_{\mathrm{Ca}}$ progressively decreased. $C$ : graph showing the fractional decrease in $I_{\mathrm{Ca}}$. The size of the 30th pulse was compared with the average size of the first 5 pulses. At fast pacing rates, $I_{\mathrm{Ca}}$ became progressively smaller. In the presence of $1 \mu \mathrm{M} \mathrm{ACh}$, the reduction was more pronounced at faster pacing rates. $* P<0.05$.
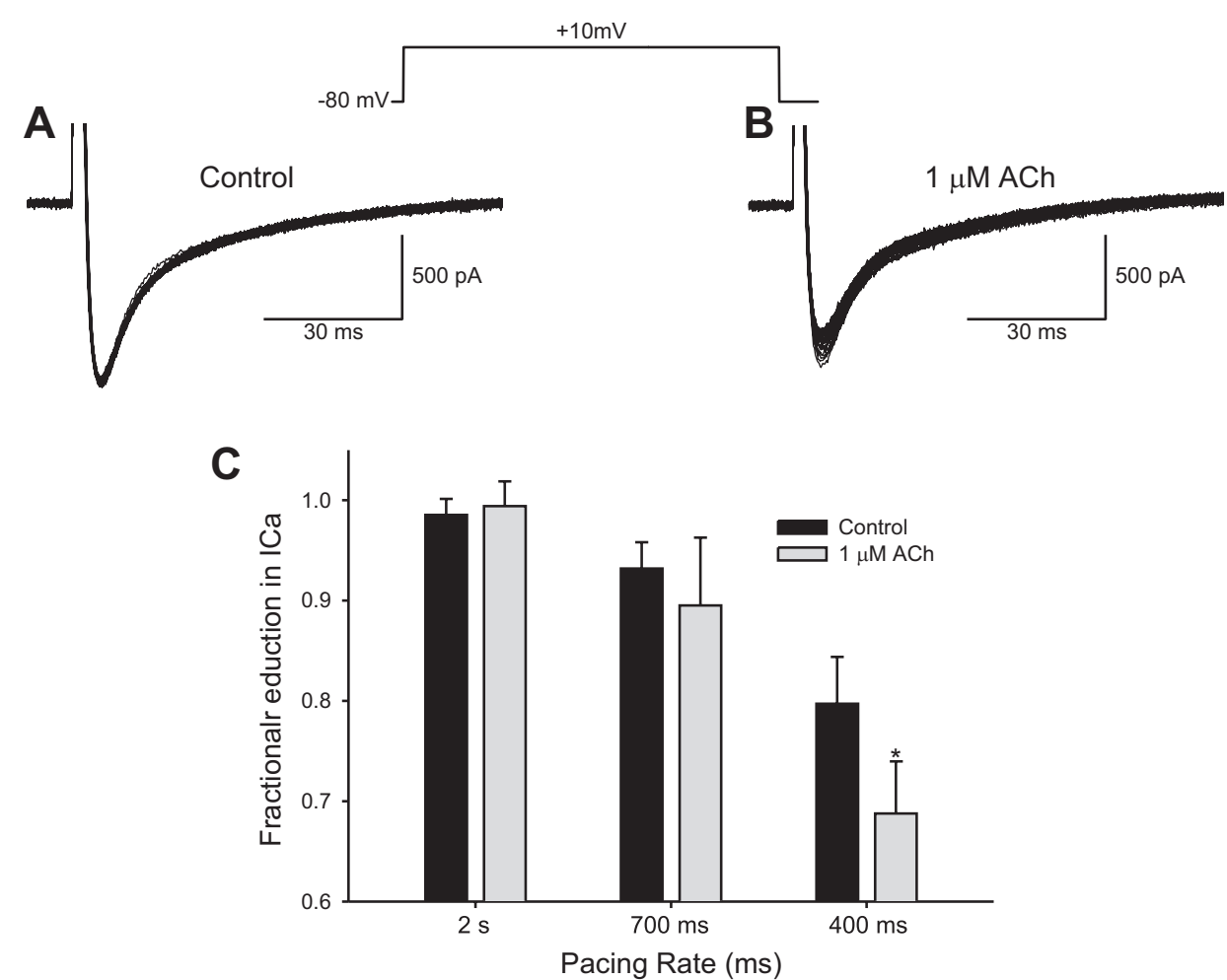

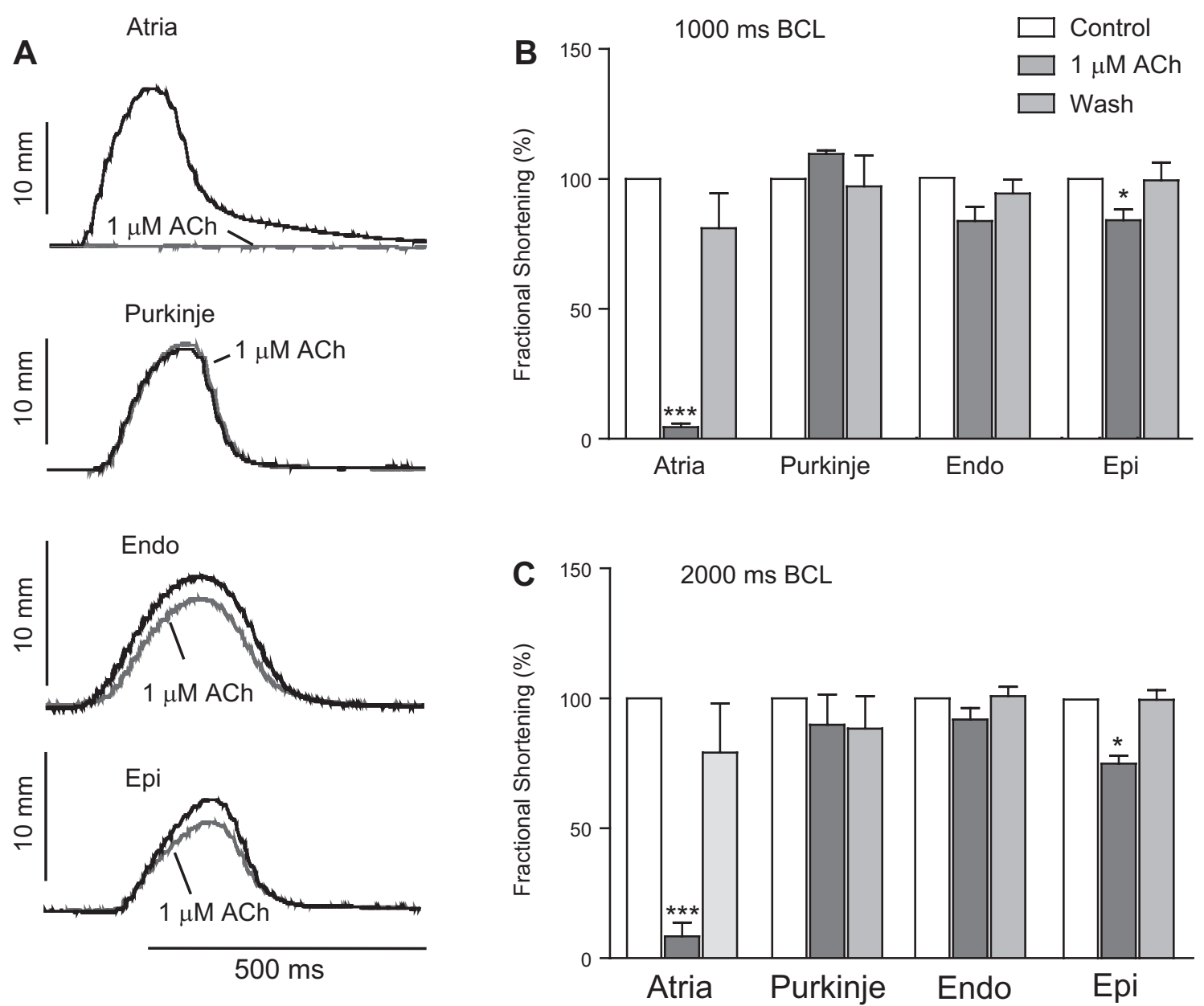

Fig. 7. Effect of ACh on unloaded cell contraction. The contraction of isolated canine atrial $(n=4)$, Purkinje $(n=6$ at $1,000-\mathrm{ms} \mathrm{BCL}$ and $n=3$ at $2,000-\mathrm{ms}$ $\mathrm{BCL})$, Endo $(n=5)$, and Epi $(n=7-8)$ cells was determined by a video edge detector in the absence or presence of $1 \mu \mathrm{M}$ ACh at $1,000-$ and $2,000-\mathrm{ms} \mathrm{BCL}$. $A$ : representative recordings. $B$ : the average of 5 consecutive recordings was calculated, and the bar graph shows the fractional shortening of cardiomyocytes in the absence or presence of $1 \mu \mathrm{M}$ ACh and after washout. $C$ : relative effect of $1 \mu \mathrm{M}$ ACh on fractional shortening.

studies by Yang et al. (35) and Litovsky and Antzelevitch (20) were before the discovery of tertiapin, and thus the specific contribution of $I_{\mathrm{K}, \mathrm{ACh}}$ to the effect(s) of $\mathrm{ACh}$ in ventricular tissue could not be addressed.

Effect of ACh on $I_{C a}$ and contraction. We compared the effect of ACh on $I_{\mathrm{Ca}}$ in isolated cells using a step protocol to a single voltage to minimize the effect of $I_{\mathrm{Ca}}$ rundown. In all cell types except Purkinje cells, there was a significant decrease in $I_{\mathrm{Ca}}$ after application of ACh. The effect of ACh on $I_{\mathrm{Ca}}$ was highly rate dependent, with the greatest reduction occurring at faster pacing rates (Fig. $6 C$ ).

In atrial cells, the increase in $I_{\mathrm{K}, \mathrm{ACh}}$ significantly abbreviated the AP and resulted in an almost complete loss of excitability. This profound reduction in cell shortening is due to shortening of the APD due to activation of $I_{\mathrm{K}, \mathrm{ACh}}$; however, a decrease in $I_{\mathrm{Ca}}$ may contribute to this effect. Interestingly, Gilmour and Zipes (13) found that application of ACh resulted in an increase in tension of free-running Purkinje fibers without an effect on APD at $1-10 \mu \mathrm{M}$. This effect was abolished by atropine, suggesting that $\mathrm{ACh}$ works through muscarinic receptor activation in Purkinje fibers. Interestingly, we observed a small increase in $I_{\mathrm{Ca}}$ in five of eight Purkinje cells after the application of ACh. Since the mean effects on $I_{\mathrm{Ca}}$ were small
(Fig. 5B), it is consistent with the lack of effect on the Purkinje AP waveform (Fig. 1B). As Purkinje fibers contribute minimally to force development in the intact heart, this increase in contraction is likely without hemodynamic consequences.

In ventricular myocytes, we found a significant negative inotropic effect of $1 \mu \mathrm{M}$ ACh in Epi cells. This is qualitatively in agreement with the observations of Yang et al. (35), who reported a concentration-dependent negative inotropic effect of $\mathrm{ACh}$ in the Epi but not in the Endo. The decrease in cell shortening was attributed to the shortening of the Epi APD; however, a small blocking effect on L-type $I_{\mathrm{Ca}}$ was found. Interestingly, exclusion of GTP from the pipette solution abolished the effect of $\mathrm{ACh}$ on $I_{\mathrm{Ca}}$, suggesting that $\mathrm{G}$ protein signaling is involved in transmitting the effect of ACh on ventricular $I_{\mathrm{Ca}}(35)$.

Radioligand binding and functional studies using several subtype-selective antagonists indicated that in the M2 receptor is by far the predominant muscarinic receptor in canine ventricular preparations (33). M2 receptors couple via a pertussis toxin-sensitive $G$ protein $\left(\mathrm{G}_{\mathrm{i}} / \mathrm{G}_{0}\right)$ to inhibition of adenylyl cyclase and a decrease in intracellular cAMP. It has been previously suggested that the effect of $\mathrm{ACh}$ on ventricular contraction is dependent on prestimulation with cAMP-elevat- 
ing agents such isoprenaline or forskolin, as reviewed by Brodde and Michel (2). As we saw a minor effect of ACh on $I_{\mathrm{Ca}}$ in the absence of prestimulation of the sympathetic system, this could suggest that activation of ventricular muscarinic receptors, even under basal conditions, may decrease the level of cAMP and thereby inhibit $I_{\mathrm{Ca}}$. Some studies have detected M1 as well as M3 receptors in cardiac tissue (for a review, see Ref. 2). $\mathrm{G}_{\mathrm{q}}$-mediated depletion of phosphatidylinositol 4,5bisphosphate $\left(\mathrm{PIP}_{2}\right)$ has been shown to attenuate $\mathrm{Ca}_{\mathrm{v}} 1.2$ by $35 \%$ (31), and recovery of the current is likely dependent on resynthesis of $\mathrm{PIP}_{2} \cdot \mathrm{G}_{\mathrm{q}}$-coupled receptors are notoriously difficult to dissect as they produce numerous downstream second messengers, and whether $\mathrm{PIP}_{2}$ depletion contributes to the observed effect of ACh on $I_{\mathrm{Ca}}$ in this study or under pathophysiological conditions remains speculative.

Summary. In the canine heart, ACh activates a large inward rectifying current, $I_{\mathrm{K}, \mathrm{ACh}}$, in atrial cells and tissues. $I_{\mathrm{K}, \mathrm{ACh}}$ was completely absent before application of $\mathrm{ACh}$, suggesting that basal or constitutively active $I_{\mathrm{K}, \mathrm{ACh}}$ is not present in healthy canine hearts. Under identical conditions, application of ACh to ventricular or Purkinje cells resulted in no current increase under voltage-clamp conditions, suggesting no measurable $I_{\mathrm{K}, \mathrm{ACh}}$ in these cell types. ACh had a minor rate-dependent effect on $I_{\mathrm{Ca}}$ that was most prominent at faster pacing, resulting in a minor inhibition of unloaded cell contraction.

Limitations of the study. The role of the parasympathetic nervous system in the ventricle may not be fully appreciated from this study because the role of accentuated antagonism was not evaluated. The sympathetic nervous system is known to exert strong influences on the electrophysiology and mechanical function of the ventricular myocardium. The ability of the parasympathetic system to antagonize these actions of the sympathetic nervous system can importantly influence its overall effect on electrophysiological and mechanical function. Substantial differences in regional expression and current levels have been reported between species as well between healthy and diseased tissue; thus, our results may only apply to healthy canine hearts.

\section{ACKNOWLEDGMENTS}

The authors are grateful to Judy Hefferon for excellent technical assistance and Dr. Robert Gilmour for helpful and informative discussions.

\section{GRANTS}

This work was supported by the Danish National Research Foundation, National Heart, Lung, and Blood Institute Grant HL-47678, New York State Stem Cell Science Grant C026424, and the Masons of New York State, Florida, Massachusetts, and Connecticut.

\section{DISCLOSURES}

No conflicts of interest, financial or otherwise, are declared by the author(s).

\section{AUTHOR CONTRIBUTIONS}

Author contributions: K.C. and J.M.C. conception and design of research; K.C., R.G., and J.M.C. performed experiments; K.C., R.G., and J.M.C. analyzed data; K.C., C.A., and J.M.C. interpreted results of experiments; K.C. and J.M.C. prepared figures; K.C. and J.M.C. drafted manuscript; K.C. and J.M.C. edited and revised manuscript; K.C., R.G., S.-P.O., C.A., and J.M.C. approved final version of manuscript.

\section{REFERENCES}

1. Bailey JC, Greenspan K, Elizari MV, Anderson GJ, Fisch C. Effects of acetylcholine on automaticity and conduction in the proximal portion of the His-Purkinje specialized conduction system of the dog. Circ Res 30: 210-216, 1972.

2. Brodde OE, Michel MC. Adrenergic and muscarinic receptors in the human heart. Pharmacol Rev 51: 651-690, 1999.

3. Calloe K, Nof E, Jespersen T, Di Diego JM, Chlus N, Olesen SP, Antzelevitch C, Cordeiro JM. Comparison of the effects of a transient outward potassium channel activator on currents recorded from atrial and ventricular cardiomyocytes. J Cardiovasc Electrophysiol 22: 1057-1066, 2011.

4. Carmeliet E, Ramon J. Effects of acetylcholine on time-dependent currents in sheep cardiac Purkinje fibers. Pflügers Arch 387: 217-223, 1980.

5. Cha TJ, Ehrlich JR, Chartier D, Qi XY, Xiao L, Nattel S. Kir3-based inward rectifier potassium current: potential role in atrial tachycardia remodeling effects on atrial repolarization and arrhythmias. Circulation 113: 1730-1737, 2006.

6. Cordeiro JM, Calloe K, Moise NS, Kornreich B, Giannandrea D, Di Diego JM, Olesen SP, Antzelevitch C. Physiological consequences of transient outward $\mathrm{K}^{+}$current activation during heart failure in the canine left ventricle. J Mol Cell Cardiol 52: 1291-1298, 2012.

7. Cordeiro JM, Ferrier GR, Howlett SE. Effects of adenosine in simulated ischemia and reperfusion in guinea pig ventricular myocytes. Am J Physiol Heart Circ Physiol 269: H121-H129, 1995.

8. Dobrev D, Friedrich A, Voigt N, Jost N, Wettwer E, Christ T, Knaut M, Ravens $\mathbf{U}$. The $\mathrm{G}$ protein-gated potassium current $I_{\mathrm{K}, \mathrm{ACh}}$ is constitutively active in patients with chronic atrial fibrillation. Circulation 112: 3697-3706, 2005.

9. Dumaine R, Cordeiro JM. Comparison of $\mathrm{K}^{+}$currents in cardiac Purkinje cells isolated from rabbit and dog. $J$ Mol Cell Cardiol 42: 378-389, 2007.

10. Ehrlich JR, Cha TJ, Zhang L, Chartier D, Villeneuve L, Hebert TE, Nattel S. Characterization of a hyperpolarization-activated time-dependent potassium current in canine cardiomyocytes from pulmonary vein myocardial sleeves and left atrium. J Physiol 557: 583-597, 2004.

11. Gaborit N, Le BS, Szuts V, Varro A, Escande D, Nattel S, Demolombe S. Regional and tissue specific transcript signatures of ion channel genes in the non-diseased human heart. J Physiol 582: 675-693, 2007.

12. Gadsby DC, Wit AL, Cranefield PF. The effects of acetylcholine on the electrical activity of canine cardiac Purkinje fibers. Circ Res 43: 29-35, 1978.

13. Gilmour RF Jr, Zipes DP. Positive inotropic effect of acetylcholine in canine cardiac Purkinje fibers. Am J Physiol Heart Circ Physiol 249: H735-H740, 1985.

14. Han X, Shimoni Y, Giles WR. A cellular mechanism for nitric oxidemediated cholinergic control of mammalian heart rate. J Gen Physiol 106: 45-65, 1995.

15. Hashimoto N, Yamashita T, Tsuruzoe N. Tertiapin, a selective $I_{\mathrm{KACh}}$ blocker, terminates atrial fibrillation with selective atrial effective refractory period prolongation. Pharmacol Res 54: 136-141, 2006.

16. Hashimoto N, Yamashita T, Tsuruzoe N. Characterization of in vivo and in vitro electrophysiological and antiarrhythmic effects of a novel $I_{\mathrm{KACh}}$ blocker, NIP-151: a comparison with an $I_{\mathrm{Kr}}$-blocker dofetilide. $J$ Cardiovasc Pharmacol 51: 162-169, 2008.

17. Heidbuchel H, Vereecke J, Carmeliet E. Three different potassium channels in human atrium. Contribution to the basal potassium conductance. Circ Res 66: 1277-1286, 1990.

18. Kovoor P, Wickman K, Maguire CT, Pu W, Gehrmann J, Berul CI, Clapham DE. Evaluation of the role of $I_{\mathrm{KACh}}$ in atrial fibrillation using a mouse knockout model. J Am Coll Cardiol 37: 2136-2143, 2001.

19. Krapivinsky G, Gordon EA, Wickman K, Velimirovic B, Krapivinsky L, Clapham DE. The G-protein-gated atrial $\mathrm{K}^{+}$channel $I_{\mathrm{KACh}}$ is a heteromultimer of two inwardly rectifying $\mathrm{K}^{+}$-channel proteins. Nature 374: 135-141, 1995.

20. Litovsky SH, Antzelevitch C. Differences in the electrophysiological response of canine ventricular subendocardium and subepicardium to acetylcholine and isoproterenol. A direct effect of acetylcholine in ventricular myocardium. Circ Res 67: 615-627, 1990.

21. Loffelholz K, Pappano AJ. The parasympathetic neuroeffector junction of the heart. Pharmacol Rev 37: 1-24, 1985.

22. Logothetis DE, Kurachi Y, Galper J, Neer EJ, Clapham DE. The $\beta \gamma$ subunits of GTP-binding proteins activate the muscarinic $\mathrm{K}+$ channel in heart. Nature 325: 321-326, 1987. 
23. Lopatin AN, Nichols CG. $\left[\mathrm{K}^{+}\right]$dependence of polyamine-induced rectification in inward rectifier potassium channels (IRK1, Kir2.1). J Gen Physiol 108: 105-113, 1996.

24. Machida T, Hashimoto N, Kuwahara I, Ogino Y, Matsuura J, Yamamoto W, Itano Y, Zamma A, Matsumoto R, Kamon J, Kobayashi T, Ishiwata N, Yamashita T, Ogura T, Nakaya H. Effects of a highly selective acetylcholine-activated $\mathrm{K}^{+}$channel blocker on experimental atrial fibrillation. Circ Arrhythm Electrophysiol 4: 94-102, 2011.

25. Makary S, Voigt N, Maguy A, Wakili R, Nishida K, Harada M, Dobrev D, Nattel S. Differential protein kinase C isoform regulation and increased constitutive activity of acetylcholine-regulated potassium channels in atrial remodeling. Circ Res 109: 1031-1043, 2011.

26. Mubagwa K, Carmeliet E. Effects of acetylcholine on electrophysiological properties of rabbit cardiac Purkinje fibers. Circ Res 53: 740-751, 1983.

27. Ravens U, Christ T. Atrial-selective drugs for treatment of atrial fibrillation. Herzschrittmacherther Elektrophysiol 21: 217-221, 2010.

28. Sanguinetti MC, Tristani-Firouzi M. hERG potassium channels and cardiac arrhythmia. Nature 440: 463-469, 2006.

29. Sarmast F, Kolli A, Zaitsev A, Parisian K, Dhamoon AS, Guha PK, Warren M, Anumonwo JM, Taffet SM, Berenfeld O, Jalife J. Cholinergic atrial fibrillation: $I_{\mathrm{K}, \mathrm{ACh}}$ gradients determine unequal left/right atrial frequencies and rotor dynamics. Cardiovasc Res 59: 863-873, 2003.
30. Shimoni Y, Clark RB, Giles WR. Role of an inwardly rectifying potassium current in rabbit ventricular action potential. J Physiol 448: 709-727, 1992.

31. Suh BC, Leal K, Hille B. Modulation of high-voltage activated $\mathrm{Ca}^{2+}$ channels by membrane phosphatidylinositol 4,5-bisphosphate. Neuron 67 224-238, 2010.

32. Ulphani JS, Cain JH, Inderyas F, Gordon D, Gikas PV, Shade G, Mayor D, Arora R, Kadish AH, Goldberger JJ. Quantitative analysis of parasympathetic innervation of the porcine heart. Heart Rhythm 7: 11131119, 2010.

33. Yang CM, Yeh HM, Sung TC, Chen FF, Wang YY. Characterization of muscarinic receptor subtypes in canine left ventricular membranes. $J$ Recept Res 12: 427-449, 1992.

34. Yang Y, Yang Y, Liang B, Liu J, Li J, Grunnet M, Olesen SP, Rasmussen HB, Ellinor PT, Gao L, Lin X, Li L, Wang L, Xiao J, Liu Y, Liu Y, Zhang S, Liang D, Peng L, Jespersen T, Chen YH. Identification of a Kir3.4 mutation in congenital long QT syndrome. Am J Hum Genet 86: 872-880, 2010.

35. Yang ZK, Boyett MR, Janvier NC, McMorn SO, Shui Z, Karim F. Regional differences in the negative inotropic effect of acetylcholine within the canine ventricle. J Physiol 492: 789-806, 1996.

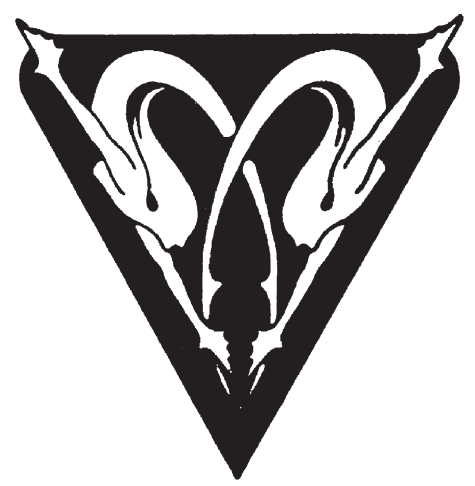

